\title{
The Engagement of BAAL - and Applied Linguistics - with Policy and Practice
}

\author{
Tess Fitzpatrick, Swansea University \\ Mike Baynham, University of Leeds \\ Guy Cook, King's College London \\ Susan Hunston, University of Birmingham \\ Ros Mitchell, University of Southampton \\ Greg Myers, Lancaster University
}

\section{Applied Linguistics: The Evolution of a Discipline \\ Tess Fitzpatrick, Swansea University}

Admission into the British Association for Applied Linguistics was subject to close scrutiny in the decade or so following the founding of the Association. Prospective members completed a questionnaire with information about their academic qualifications, teaching and research activities, membership of other associations, and details of two referees who would vouch for their suitability as members of BAAL. The referees then completed their sections of the form and forwarded it to the BAAL committee members, three of whom were tasked with scoring the application. If the scores did not reach a certain threshold, the

How to cite this book chapter:

Fitzpatrick, T., Baynham, M., Cook, G., Hunston, S., Mitchell, R. and Myers, G. 2019. The Engagement of BAAL - and Applied Linguistics - with Policy and Practice. In: Wright, C., Harvey, L. and Simpson, J. (eds.) Voices and Practices in Applied Linguistics: Diversifying a Discipline, pp. 13-31. York: White Rose University Press. DOI: https://doi.org/10.22599/BAAL1.b. Licence: CC BY-NC 4.0 
application was referred to the whole committee. If approved, membership was confirmed on receipt of the (post-decimal) $£ 1.05$ entry fee and $£ 1.25$ annual subscription.

The original version of the application form, used until 1969, had an additional question: 'State why you wish to join the Association, what benefit you expect to obtain from it and what contribution you will be able to make. There was broad consensus that the expected benefit was to exchange ideas, experience and knowledge, and to foster collegiality in a world where many were working in isolation. Eagerness to meet colleagues in allied professions and fields was a common theme, as was 'encouraging dialogue', especially between teachers and linguists. BAAL was cited by one applicant as the only professional association which brings together those concerned with the application of linguistics to language.'

Statements about 'the contribution you will be able to make' follow this theme of sharing expertise and ideas, and are modestly expressed. The actual contribution to applied linguistics of many of these early members is evident, 50 years later, on bookshelves across the world; many of them went on to produce texts that are core to our discipline. And applied linguistics is now a discipline in its own right, recognised in establishment documents such as QAA benchmark statements and REF criteria statements, and in degree programmes around the world, but when its formation was announced in the Newsboard section of the ELT Journal in May 1968, it was defined by its connections with other, established, disciplines:

The aims of the Association ... are defined as being to promote the study of problems of language acquisition, teaching and use, and to foster inter-disciplinary collaboration in this study'. Its field of interest can therefore be taken to include relevant aspects of linguistics, psychology and sociology.

(Newsboard 1968: 280-281)

To what extent did the early members of BAAL fit this intended focus? Interests declared by those who joined in the first two years include: the relationship between linguistics and the teaching of modern languages; the 'application of linguistics to ... the teaching of English as a native language'; linguistic stylistics; application of linguistics to the study of speech pathology; teaching English, including to immigrant communities in the UK; and new teaching methods, with use of language laboratories and audiovisual techniques particularly prevalent. In many cases this can be seen as 'linguistics applied' (see Cook's commentary later in this chapter), but the kernel of identifying features of 'applied linguistics' is there too, as early members categorise themselves as having both academic and professional interests. Typically they had recently completed postgraduate study, but had already accrued professional experience in roles including modern languages teacher/examiner, British Council 
education officer, education adviser to overseas government, RAF linguist, Royal Navy education advisor, coursebook writer, speech therapy trainer, television and radio (BBC) language course scriptwriter/broadcaster, English language teacher overseas and for immigrant communities in UK, language laboratory installer and teacher trainer. These people had first-hand experience of the 'problems of language acquisition, teaching and use' and embodied the bridge between theory and practice (in other words, between the 'theoretical and empirical investigation' and the 'real-world problems' of the much-cited 1995 Brumfit definition).

Careers spanning professional practice and academic scholarship are still not unusual in applied linguistics; the contributors to this chapter, all former chairs of BAAL, share that profile. This is not so commonly seen elsewhere and can perhaps be seen as a distinct feature of our discipline. It is surely unusual too for a discipline to define itself, in the aim stated in that 1968 announcement, as being interdisciplinary. So, a focus on intersections, interfaces and interpretations, an appreciation that the most exciting insights can be found where disciplines meet, and an understanding of how to navigate the shared (or abandoned) territory between disciplinary perspectives and between research and practice are also, perhaps, distinguishing features of the applied linguist.

The 2014 Research Excellence Framework evaluation brought the notion of a research-practice interface into mainstream UK academic discourse, in the form of engagement and impact (defined as 'an effect on, change or benefit to the economy, society, culture, public policy or services, health, the environment or quality of life, beyond academia'). Only 30 of the 6,000+ case studies submitted to REF2014 refer explicitly to 'applied linguistics', although an applied linguist might see evidence of our discipline in many others too (https://impact.ref. ac.uk/casestudies/). Those 30 could be seen to offer a snapshot of the scope and reach of 21st-century applied linguistics, though: topics covered include intercultural communication, multilingual education, language and gender, 'global' skills, language policy in multicultural UK, language testing, social justice in LGBTIQ communities, health communication, ecological linguistics, forensic linguistics informing police practices and voice analysis, bilingual communities, public understanding of language variation, language teaching techniques, tools and ontological approaches, preservation of endangered languages and promoting languages in school. Would the founders of BAAL recognise their vision of 'applied linguistics' in these projects? Well, the linguistics, psychology and sociology interface is certainly detectable in the topics listed, though the study of language use seems slightly more prevalent than of language acquisition and teaching in this UK snapshot. There is a strong theme of social accountability and social justice. The demands of REF do not necessarily make for representative sampling of the discipline, of course: there is more reference here to language as a social phenomenon than as a mental phenomenon, though plenty of applied linguists are working on the latter. 
That capacity to reach out from the academy in order to engage effectively with policy and practice is the focus of what follows in this chapter. The title of the chapter acknowledges that, while BAAL and applied linguistics are not synonymous - many people working in applied linguistics do not call themselves applied linguists, and many are not members of BAAL - their trajectories, in the UK at least, are intertwined. Here we, as former chairs of BAAL, offer four perspectives on 'the engagement of BAAL and the discipline of applied linguistics with policy and practice, followed by a commentary on those reflections, and a call to arms. In the next section of the chapter, Greg Myers identifies themes and patterns that emerge from scrutiny of the history of BAAL, and the following three sections see Rosamond Mitchell, Mike Baynham and Susan Hunston track and detail developments in three areas of connection between BAAL and policy/practice. These are language education in schools (Mitchell), adult literacy and ESOL (Baynham), and the role of applied linguistics in understanding the society we live in and the role of BAAL in shaping applied linguistics (Hunston). Guy Cook's critical commentary reflects on these and other perspectives on applied linguistics, and seeks evidence of a disciplinary unity or identity as BAAL - and applied linguistics in the UK - enters its second half-century.

\section{Engagements with Policy and Practice in the BAAL Archive Greg Myers, Lancaster University}

When I was reading through the BAAL archives and interviewing past chairs, I was struck by how often issues that seem current now started much earlier in BAAL history. For instance, efforts to engage with the social and educational policies of the UK and with the practices of language professionals run through the whole history of BAAL. Paralleling this is an ongoing discussion of how BAAL itself should change to reflect wider social realities. What follows are some notes drawn from the History of BAAL that Rosamond Mitchell prepared for the 30th anniversary and I updated for the 50th anniversary (BAAL 2017).

\section{Engaging with policy}

BAAL has tried to bring linguistic knowledge to bear on public issues where language plays a role. One such policy area is the teaching of English in UK schools. BAAL contributed submissions to the Bullock Committee (1973), the Kingman Committee on the Teaching of English Language (1987), and consultations on various versions on the National Curriculum for English. Comments were produced on English 5-16, and on the Report of the Swann Committee on the Education of Ethnic Minorities (1985). The final reports produced by all these bodies have also been extensively debated at Annual Meetings and 
Seminars, and in the columns of the Newsletter. In 1988-91, Michael Stubbs was a member of the Cox Committee, which produced the first National Curriculum proposals for English. Ronald Carter was director of the Language in the National Curriculum (LINC) Project, the national in-service teacher training project intended to improve teachers' language knowledge and language pedagogy skills (1989-92). When the materials produced by LINC were suppressed by government ministers on grounds of their overly sociolinguistic orientation, BAAL participated in the public protests.

Since 2000, interventions by BAAL in public policy have often concerned wider issues of language in society, especially around diversity and migration. These interventions include:

- a defence of 'cultural diversity and language learning' in a letter to Home Secretary David Blunkett after his statement that bilingual families should speak English at home (2002);

- a criticism of unscientific use of language analysis in examining the cases of asylum seekers (2003);

- criticism of decisions that both raised the requirements for English skills by immigrants and withdrew free ESOL provision that might enable them to meet these requirements (2007);

- a criticism of the introduction by the Home Office of pre-entry language tests for spouses hoping to join their families in the UK (2008);

- a criticism, again addressed to the Home Office, of the use of English testing in immigration cases (2012);

- joining the Communication Rights Group, a consortium of linguists across Australia, North America and the UK, in recommending guidelines for communicating rights to non-native speakers of English in Australia, England and Wales, and the USA (2016);

- a statement to key policymakers, with six other learned societies, on linguistic issues in Brexit (2017).

As this list shows, BAAL usually makes a statement when there is broad academic consensus about the linguistic issues, even if the wider political issues may be highly controversial.

Alongside these formal institutional statements, BAAL has tried to engage with the constant stream of public discussion about language issues, in the press, broadcasting and social media. Sometimes this media discussion brings welcome publicity to work on education, sociolinguistics, forensic linguistics or corpus linguistics. But media reports can also be ill-informed, misrepresenting academic research or drawing on no research at all. The problem for BAAL interventions, as an organisation, is that by the time an inquiry from the press has been routed to the correct person, or a press release has been drafted and checked, the news cycle has moved on. For instance, in 2013, a headteacher in Middlesbrough asked parents not to let their children use at home a list of 
lexical items that she declared to be 'dialect'. Twitter and BAALmail erupted with criticisms, but by the time a statement was possible, it was too late to be used by the press.

One indication of the engagement of BAAL with wider social and policy issues is the list of plenary speakers included in the history. The speakers often seem chosen by the local organising committee to suggest that an area that may not be covered in many papers at the conference at the moment, is worth more attention. So, for instance, the very first set of what we would now call plenary speakers, in 1978, included Eric Evans from the National Language Unit of Wales, talking about the preservation of Welsh, and Verity Saifullah Khan from the ESRC Research Unit on Ethnic Relations, talking about minority languages. Later examples of policy-relevant plenaries include Colin Williams (1990), William McLeod (2010) and Kathryn Woolard (2013) on language policy issues, Deborah Cameron (1992) on language and gender, Norman Fairclough (1994 and 2008) analysing government policy documents, Rick Iedema (2011 and 2015) on language in the workplace, Ingrid Piller (2016) on multilingualism in a legal context, Barbara Seidlhofer (2001) and Anna Mauranen (2012) on English as an international language, and Bencie Woll (2000 and 2017) on British Sign Language. Of course, many other plenaries had implications for education and language policy, but these give some idea of the range.

\section{Engaging with professional practice}

The main forum through which BAAL has intervened in the practices of teachers is CLIE, the Committee on Language in Education. CLIE emerged from a joint LAGB-BAAL seminar on the teaching of languages in schools at North Worcestershire College of Higher Education in 1978. Over the years, it has had projects on the preparation of teachers, on knowledge about language in teaching, and on getting an A level exam in linguistics. It has also responded to government consultations on such issues as the National Curriculum, primary education, and the training of teachers.

BAAL has been more cautious about intervening directly in the teaching of English as a foreign or additional language. For instance, there has been discussion over 30 years about setting academic standards for TESOL courses, but the task was taken up by other organisations, such as the British Association of TESOL Qualifying Institutions (BATQI, 1991-2010), the British Institute for English Language Teaching (BIELT, 1999-2002) and the Association for Promotion of Quality in TESOL Education (QuiTE, 2001-12), often with BAAL members involved.

One area of practice that involves BAAL is the recruitment of teachers. BAAL has set criteria for the content of advertisements appearing on BAALmail, including both UK law (no discrimination on the basis of gender or age) and 
also its own policies. In 2011, the EC decided it would not accept advertisements requiring applicants for posts to be 'native speakers'. Of course, BAAL refusing an advertisement does not change discriminatory hiring practices, but it does lead to discussions around identities and ideologies.

\section{BAAL organisation}

Scholars who study diversity in society have often raised issues about the diversity of BAAL, in its membership, attendance at meetings, and composition of the Executive Committee. I wonder if you can guess the date of this message from a BAAL chair:

I think, too, that we should be more conscious than we have been about the composition of our membership. In a profession with a higher proportion of women than most, our work has still led to a succession of male chairpersons (though I should add that the relative numbers of officers and committee members compare favourably with most organisations). Further, it is increasingly true that applied linguistic work is being carried out by members of minority language-speaking communities; BAAL must ensure that its membership reflects this fact if it is to speak for the many social and political aspects of language that require current comment. Similarly, with language and ethnicity now a major concern of many members, we need more black members. At the same time, of course, it would be much easier to recruit in these groups if there were more people appointed to university and college posts with such backgrounds.

This is Chris Brumfit, writing in BAAL News in 1985. It is interesting that the newsletter carried a criticism of all-male panels (at AILA) as early as 1983 (the letter was from Robert Phillipson and Tove Skutnabb-Kangas). A formal equal opportunities statement was adopted in 1995, leading to an EC audit of its own practices as a follow-up. And these issues were raised again in discussion of the all-male plenary list in 2014.

On the issue of gender equality, BAAL has made some progress: half the chairs since 1997 have been women. But Brumfit raises two other issues that are still challenges now, expanding the involvement of UK speakers of minority languages and of members of ethnic minority groups. It could be said that we do have a wider range now, because of the broader international attendance. But the diversity of UK participants, in some dimensions, is limited now as it was limited then by the unrepresentative composition of academic departments. (Interestingly, the Executive Committee is usually more diverse than most large departments.) So, if we want to make BAAL broadly representative of British society, we have to address a much wider systemic issue. 


\section{BAAL, Applied Linguistics, and Language(s) in School Rosamond Mitchell, University of Southampton}

The success of applied linguistics as an international academic discipline is in large part due to the rise of English as a global language. However, it is clear that applied linguists have never limited their interests to international English. From its foundation in 1967, BAAL set out to inform language education of all kinds, with insights from the language sciences (Mitchell 1997). This contribution reviews the historical impact of applied linguists on language education in British schools, and makes brief proposals for sustaining and developing this impact in future.

The records of BAAL make clear its historic educational ambitions to promote:

- the understanding of linguistics and a principled approach to developing knowledge about language;

- understanding of the central educational role of language and 'language across the curriculum';

- links between the teaching of English and of other languages;

- positive attitudes towards multilingualism and the use of multilingual approaches in education incorporating community/heritage languages;

- effective pedagogy for languages and for literacy.

Regarding the curriculum and pedagogy of English, where established tradition favoured a literature-led approach, applied linguists have consistently aimed to promote linguistic perspectives through participation in diverse projects and review groups, promoted firstly by the Schools Council, and later by the Department for Education and Science: major examples are the curriculum materials project 'Language in Use' (Doughty et al. 1971); the Kingman and Cox committees, whose reports made proposals for promoting systematic language study in the new National Curriculum for schools (DES 1988, 1989); and the Language in the National Curriculum (LINC) project intended to contribute to teachers' professional development with respect to English language (Carter 1990, 1996). They provided input and critical commentary on the evolving National Curriculum for English (CLIE 1993, 2011), the National Literacy Strategy (Bourne et al. 1999) and the introduction of synthetic phonics (Ellis \& Moss 2014). A significant success was the introduction of English language at A level (Goddard 2016); however, applied linguists generally failed to make headway against an increasing policy focus on Standard English taught as a discrete subject. For example, the sociolinguistic focus of the LINC proposals and its acknowledgement of language variation was ultimately rejected by ministers, so the project was scrapped and its findings excluded from the teacher education curriculum.

Regarding foreign languages, applied linguistics perspectives were promoted by the government-funded Centre for Information on Language Teaching 
and Research (CILT) until 2011, when the main centre in England was closed (Hawkins 1997). From the late 1970s, successive CILT directors set out to promote an integrated view of language across the curriculum through the National Congress on Language in Education (NCLE), bringing together professionals concerned with English, with foreign languages and with community languages (Perren 1979; Davidson 1981; Moys 1984; Trim 1997). During the 1980s, this initiative became irrelevant following policy commitment to a National Curriculum which was competency-based in inspiration and grounded in discrete curriculum subjects, including 'English' and 'modern foreign languages'; the main legacy of NCLE was the international 'language awareness' movement (Hawkins 1984; Donmall 1985; Daborn 2016).

Concerning MFL, the National Curriculum of the 1990s promoted a languages for all' philosophy, with the expectation that all secondary school students would study a foreign language to GCSE level. However, by the early 2000s this proposal was not seen as viable, and language study became optional from age 14. In compensation, the government adopted a National Languages Strategy, which was meant to enhance the voluntary study of languages, and which also seriously promoted languages in the primary school (DfES 2002); here, CILT played an especially active role throughout the 2000s.

Meanwhile, John Trim (CILT director from 1978 to 1987) promoted European initiatives in competency-based foreign language education, ultimately resulting in the Common European Framework of Reference for Languages (CEFR: Council of Europe 2001). However, UK reluctance to engage with European educational initiatives meant that the CEFR was never endorsed as a framework for home FL instruction. Instead, a locally produced 'languages ladder', developed as part of the National Languages Strategy, provided the basis for a professionally developed, independent set of language assessments in a range of languages ('asset languages': Jones 2007). It was hoped that this assessment scheme would motivate and provide certification for learners undertaking study of languages below GCSE level, for example in primary schools. However, with the ending of the NLS in 2011, asset languages was also no longer supported.

Applied linguists with interests in foreign language education have had some policy traction during the evolution of the National Curriculum for MFL, especially through the work of CILT. However, since the closure of CILT and abandonment of the National Languages Strategy, though individuals and groups continue to offer research-based commentary on policy and practice (CLIE 2017; Marsden 2016; Mitchell 2011, 2013; Mitchell \& Myles forthcoming), current challenges to applied linguistic perspectives on schooling remain strong. An assessment-driven curriculum retains clear subject boundaries (Marsden 2016), and the most recent recasting of the National Curriculum reflects ministerial preference for traditional practices in both English and MFL (Wyse \& Torgerson 2017). There is a mismatch between current curricula and teaching practice and an increasingly multilingual school population. Teacher education 
has very limited subject-specific content (Teaching Schools Council 2016), and practising language professionals have limited opportunities for subjectspecific CPD and are disengaged from research (Marsden \& Kasprowicz 2017). Resources are squeezed across the system, further discouraging innovation. Under these conditions, though study of a foreign language was made a compulsory element in the National Curriculum for English primary schools in 2014, schools are clearly struggling to resource and implement languages provision with any consistency (Tinsley \& Board 2017), and delivery of both English and MFL remains cramped by assessment backwash throughout the system.

Against this backdrop, applied linguists continue to proffer advice and commentary, responding to government consultations etc. More importantly, they continue to incubate alternative perspectives on language education, through special interest groups, seminars and workshops (many BAAL-sponsored), and through courses, blogs and provision of resources (e.g., Giovanelli \& Clayton 2016). University centres engage with local and national school and teacher networks to promote e.g. multilingual pedagogic practices and multiliteracy (see for example the MOSAIC group at the University of Birmingham or the Centre for Language, Culture and Learning at Goldsmiths); effective researchled grammar pedagogy (for example at University College London: see https:// grammarianism.wordpress.com/courses/); or effective primary languages practice (for example through the Research in Primary Languages network: see www.ripl.uk/network/). Overall it has to be concluded that this kind of local, bottom-up activity is essential to keep in being a range of research-informed perspectives on language, and support varied professional practice, and that this is the best kind of 'impact' that applied linguists can currently offer independently to support educational resilience into an especially uncertain future. To impact national education policy more proactively and systematically, it seems likely that larger alliances will be needed in which applied linguists combine with academic communities in other fields (social science, computer science/ engineering, education) and offer a unified 'expert' voice on a larger scale.

\section{BAAL, Applied Linguistics, and Adult Language Education: ESOL, Literacy, Multilingualism and Diversity Mike Baynham, University of Leeds}

My perspective here is from a concern throughout my career with the language education of adults, most specifically ESOL and literacy, in the context however of multilingualism and diversity. I am going to start by recalling the year 1985 when there was I think a decisive opening out of the scope of applied linguistics to include all aspects of what Chris Candlin called language in social life. Any aspect of the social world it seems can attract the attention of applied linguists. Prior to this, applied linguistics had sometimes seemed simply the theoretical wing of the EFL business. It was a year for example in which a whole new 
approach to the study of literacy began to emerge, which was to engage me, following the publication of two seminal works: Shirley Brice Heath's 1983 Ways with Words and Brian Street's 1984 Literacy in Theory and Practice. There was a move to develop a research basis for adult literacy building on this work which took the gaze of the researcher away from the classroom to investigate literacy in the social world, which became known as the new literacy studies. Street was an inspirational figure here, and there was important work done in Lancaster by David Barton, Mary Hamilton (e.g., Barton \& Hamilton 1998) and by others, in the UK and elsewhere, myself included. So this is an example of an outgrowth of applied linguistic research to engage with a new problematic.

So where was adult ESOL (or, as it was then known, adult ESL) in this? The 1970 s and 1980s was a period of considerable development in the UK, but the emphasis was more on curriculum and methodology. A representative publication was Nicholls and Hoadley Maidment's Current Issue in Teaching English as a Second Language to Adults (1993). It was also the period of the founding of the NATECLA journal Language Issues. It is curious to wonder why there was not a parallel development of a research agenda to that in adult literacy. Perhaps this was because there was a readily available body of research on second language learning and teaching to be drawn on, which made the need for a specifically adult ESOL research agenda less pressing. There were of course important exceptions to this, such as the collaboration between John Gumperz and the Industrial Language Training Unit in Southall, which led among other things to the video CrossTalk. Another research project of the period, the ESF Ecology of Adult Language Acquisition (EALA) project (Perdue 1993) also fitted the bill, in researching the naturalistic or informal language learning of adult migrants, but this did not perhaps have the same impact on the field as the Gumperz ILT collaboration did. The picture was very different in Australia, where, for example, Michael Clyne had already published his seminal Zum PidginDeutsch der Gastarbeiter (Clyne 1968), which focused attention on so-called naturalistic SLA, and the Adult Migrant Education Programme had a well-funded research and development arm, NCELTR, based at Macquarie University and directed by Chris Candlin. Also significant in the Australian context was Joe Lo Bianco's Australian Language Policy (Lo Bianco 1987), subsequently the Australian Language and Literacy Policy, which looked at language policy and practice through a multilingual lens.

It was not until the 2000s in the UK that a similar move led to the funding of research to support the National Curriculum in Adult Literacy, Numeracy (and ESOL), leading to the establishment of the National Research and Development Centre (NRDC) and a suite of research projects which went some way to establishing a research agenda for adult ESOL. Arguably these initiatives did not have the reach achieved in Australia in the 1980s and 1990s, since multilingualism was not included in the policy mix; indeed, as the decade wore on the UK mood shifted to an emphasis on securing borders, integration and citizenship. This entailed a move away from the focus on multiculturalism and 
diversity towards national borders and citizenship, strongly in evidence to the present as we see the role for Brexit extremists of securing national borders trumping (and I use the verb advisedly) considerations of the economy and the preservation of the social fabric in the UK. I think it is fair to say that King's College London and Leeds have taken a leading role in the development of this research agenda both through funded research projects and a cohort of practitioner PhDs researching ESOL-related topics. I am thinking here of the research and activist leadership shown by James Simpson at Leeds and Melanie Cooke at King's (e.g., Cooke \& Simpson 2008). In my own career I have worked across adult literacy and adult ESOL. My work in Australia in the 1990s focused primarily on literacy, but when I returned to the UK in 2000 as professor of TESOL, my attention naturally turned to the relatively undeveloped research area of adult ESOL. I was lucky to be able to play a role in the ESOL research activities of the NRDC, often in partnership with Celia Roberts at King's in a series of projects such as the ESOL Effective Practice Project (Roberts \& Baynham 2006). We wanted to locate adult ESOL research in a broader context, that of the trajectories of migration, in contexts of language learning and use in multilingual and diverse contexts. Our ongoing research in Leeds led to the opportunity to work on the Translation \& Translanguaging project, led by Angela Creese at Birmingham, productively bringing together long-standing interests in researching multilingualism with a critical perspective on some of the important issues in migration and settlement.

Adult ESOL, like so many other areas, is a field hollowed out by a decade and more of under-funding and austerity, yet there are promising signs of research activity as described above and activism such as the Save ESOL campaign, which sprang out, as a response to government cuts to the sector, from networking online on the Adult ESOL Research List, hosted by James Simpson. Another small but promising green shoot was the ESRC Queering ESOL seminar series [queeringesol.wordpress.com], jointly convened by John Gray, Melanie Cooke and myself, again a product of online networking on the Adult ESOL Research List and the activism of such as Laila al Metoui, who convened the first adult ESOL LGBTQ event with funding from the British Council. If, as seems increasingly possible in these troubled times, we start to see a decisive move away from the era of austerity towards social reconstruction and growth, there are research-informed ideas and energy that can be put to work to support the reimagining of adult ESOL in a post-austerity UK.

\section{BAAL, Social Research and the Identity of Applied Linguistics Susan Hunston, University of Birmingham}

Below I address two questions: what is the contribution of applied linguistics to social research, and what is the identity of applied linguistics as an area of academic study? 


\section{Applied linguistics and social research}

A major strand of research in applied linguistics is what might be described as the study of language (discourse) in a social context. Over-simplifying somewhat, such research may have the aim of describing how entities, including people, are construed by language, or of describing how actions or effects are achieved through language. Examples would include the construal of academic identity (Hyland 2012), or the exercise of power in courtrooms (Wodak 2009), the construction of roles in workplaces (Koester 2011), or the effectiveness of kinds of classroom interaction (Chaudron 1988). All this research draws on a shared understanding of language as formative of institutions, cultural assumptions, knowledge and opinions. That shared understanding might be considered essential to applied linguistics. There is, however, a diversity of approaches realised in multiple research methods. These include in-depth qualitative and explanatory studies associated with ethnography, conversation analysis or genre studies, and larger-scale quantitative studies associated with corpus linguistics. Recent developments can be summarised in terms of the following:

1. There has been an increase in the number of projects making use of large-scale data and what might be described as basic corpus investigation techniques. (At the same time, corpus linguistics itself has become a great deal more quantitative in its approach and probably further removed from application.)

2. There has been an increase in the number of projects making use of multimodal data, setting language use alongside other semiotic systems. Studies of newspaper articles typically include an analysis of accompanying visuals (Bednarek \& Caple 2012). Studies of spoken interaction are likely to include an analysis of gesture (Adolphs \& Carter 2013).

3. There is an emphasis on the constitutive, as opposed to representative, role of language, and a re-evaluation of the relationship between the individual and society. Examples would include the performativity view of gender and sexualities (Cameron 1996), or the reconceptualisation of phenomena formerly accounted for by 'code-switching' as 'translanguaging' (Li 2017). Along with this might be said to be a move towards disruptive categories and a challenge to theoretical assumptions.

4. At the same time there is a widening of range of contexts to which applied linguistics is applied, with an emphasis on problem-solving and practicality, particularly in fields such as health care (Brookes et al. 2018).

Innovation in these areas of applied linguistics lies both in the generation of descriptions of novel data and in the development and testing of models accounting for language use. What is particularly apparent is the uncovering of patterns that might be said to be hidden in plain sight - aspects of language use that are unremarked and normalised but whose use has significant social 
effects. Questioning patterns in doctor-patient interactions is one example, and the phenomenon of collocation another.

\section{The identity of applied linguistics}

We might look at the question of the identity of applied linguistics from internal' and 'external' perspectives. Internally, the diversity of research under the broad heading of applied linguistics is recognised and welcomed, as is apparent from the range of (currently 13) BAAL SIGs, which themselves represent only part of the diversity in focus. I believe the ethical stance of BAAL is important in maintaining this unity within diversity. Institutionally, applied linguists find themselves in many different kinds of hybrid academic unit. Inevitably, we tend to define ourselves in contrast to our colleagues, that is, what we are not as much as what we are. Broadly speaking, applied linguists might see themselves as different from (if not in opposition to) general linguistics (if they are located in a linguistics department), literary/cultural studies (if they find themselves in an English or modern languages department), and quantitative survey approaches (if they are situated in an education department). There are reflections of this on REF panels, where BAAL has always been concerned to ensure adequate representation on the Education panel, the Modern Languages \& Linguistics panel and the English Language \& Literature panel. Applied Linguistics does seem to be unusual in the number of panels that an individual could be returned to, based not on genuine difference but simply on the vagaries of university organisation. There is a similar concern that the ESRC grant approval panel that considers linguistics applications should include at least one applied linguist. In all these discussions there is an emphasis on the distinctiveness of applied linguistics and a demand that it not be subsumed under the heading of linguistics.

Is this insistence on the distinctiveness of applied linguistics appropriate? Given that both linguistics and applied linguistics incorporate a large number of subfields, insisting on a strict division between the two is probably not defensible. On the other hand, given that variety, stressing the importance of a breadth of view from gatekeepers is important to both disciplines, and if referring to them as two disciplines helps that aim then so much the better.

\section{Commentary}

Guy Cook, King's College London

Time that is intolerant

Of the brave and innocent,

And indifferent in a week

To a beautiful physique, 
Worships language and forgives

Everyone by whom it lives;

Pardons cowardice, conceit,

Lays its honours at their feet...

(Lines from In Memory of W.B. Yeats, later repudiated by their author, W.H. Auden)

This present multi-authored colloquium-engendered chapter marks 50 years since the foundation of BAAL. Applied linguistics, and particularly British applied linguistics, is very fond of such anniversaries, using them as an opportunity for reminiscences - some rather sesquipedalian.

For BAAL members these introspections have a certain interest, both personal and intellectual. Who are we? Where did we come from? Where are we going? Why are we here? These are important questions in any enterprise. But we need to be careful too. Our memories are of little interest to people outside applied linguistics, although it is for them that we ought to answer these ontological questions. Autodiegetic reminiscences, moreover, tend to be selfcongratulatory, when what we need is self-criticism: there is much to regret as well as celebrate in the history of BAAL. By analysing what has gone wrong we may escape creeping stagnation.

Fifty years ago the new subdiscipline of applied linguistics was a straightforward affair. Its main job was to hand down insights from linguistics to language teachers, especially teachers of EFL - a pedagogy then innocently untroubled by our current worries about linguistic imperialism, native speakerism and so forth.

Rightly and inevitably applied linguistics moved away from this remit. Two particular developments in the 1980s and 1990s led the way. Henry Widdowson (1980) inspiringly suggested that rather than merely funnelling linguistics into pedagogy the discipline should mediate between the two, adding to both, becoming applied linguistics not just linguistics applied. Then his colleague Christopher Brumfit presciently suggested an expansion beyond language teaching to embrace all 'real-world problems' in which language is a central issue (Brumfit 1995). These two complementary ideas provided for their time a coherent and principled underpinning for the theory and practice of applied linguistics.

The other voices in this joint article document this expanded scope of applied linguistics promoted by Brumfit. Ros Mitchell tells us of its engagement, from relatively early on, with the teaching of English and modern languages in British schools, Greg Myers of its 'efforts to engage with the social and educational policies of the UK and with the practices of language professionals', Mike Baynham of its role in TESOL and debates around migration and multiculturalism. Susan Hunston gives further examples of diverse applied linguistic work on 'academic identity ... power in courtrooms ... roles in workplaces [and] classroom interaction. She sees these disparate areas as united by their interest in 'language (discourse) in a social context' and also by their relentless focus on data. To all these one could add many more: forensic linguistics, lexicography, 
speech therapy, translation studies and so on. And on. It is a growing list. But it is in danger of being only a list if it has no theoretical base.

Many of us flounder when asked to define applied linguistics, retreating into vague generalities about language in society, or sidestepping the problem by cataloguing the size of current databases and the power of the software used to analyse them. Yet these generalities can disguise an absence of underpinning conceptualisation. Moreover, the current ascendancy of data-based study can be detrimental to the theory and introspection which the best empirical study always needs as a companion, and which characterised applied linguistics in the 1980s and 1990s. Eulogies of advances in data analysis are often accompanied by insistence that language is only external and social, and denial that it is also cognitive and internal: a tool for thought not just communication (Berwick \& Chomsky 2017: 55-74), thus cutting us off from a substantial part of contemporary linguistics. This severance is as damaging to us as the converse insistence that language is only cognitive has been to theoretical linguistics. Language and discourse are not synonyms as Hunston seems to suggest.

Yes, applied linguistics has diversified and expanded since 1967. This brings dangers as well as benefits, however. The expansion has also entailed dilution and evaporation. In the name of interdisciplinarity, we are involved and often absorbed by all sorts of other disciplines, many much older than ours (lexicography, translation). Many of those involved in this interdisciplinary study have in reality left applied linguistics for other disciplines. And many who are nominally applied linguists make no attempt, being busy elsewhere, to engage with BAAL or other disciplinary fora, including the major journals.

As the other contributions make clear, the history of BAAL in Britain has often been marked by a failure to influence issues about language in society, especially in education. It is easy to blame the depressing succession of reactionary ministers of education in Britain over the last 50 years, and they have indeed been very much at fault. Yet the fault is ours too. Greg Myers mentions a case in point. Writing of BAAL's reaction to the attempt by a Middlesbrough primary head to ban the use of dialect in her school, he notes the lengthy debate which ensued among BAAL members on Twitter and BAALmail, and how 'by the time a statement was possible, it was too late to be used by the press. We have been too busy engaging with ourselves to have the influence which an applied discipline ought to have.

So there is a lot to be done if applied linguistics is to survive and thrive for another 50 years. I do not know how to achieve this; it is something for younger members, not so tangled up in memories as we five. But a way needs to be found - to engage not just with ourselves and those who agree with us but also with those who disagree, commentators on language from outside the academy: politicians, pundits, journalists. For this we need a coherent definition of what applied linguistics is: a theory as well as a practice, ideas as well as data. This is a difficult task but one we need to tackle, so that 50 years from now we might be able to say that we have agreed and engaged not only with each other, but with the outside world as well. 
Maybe we should take a lesson from W.H. Auden and not feel obliged to hang on to past 'achievements'. Think more about the future instead.

\section{References}

Adolphs, S. and Carter, R. 2013 Spoken corpus linguistics: From monomodal to multimodal. London: Routledge.

BAAL 2017 Notes on the history of the British Association for Applied Linguistics 1967-2017. Available at https://baal.org.uk/history [Last accessed 3 January 2019]

Barton, D. and Hamilton, M. 1998 Local literacies. London: Routledge.

Bednarek, M. and Caple, H. 2012 News discourse. London: Continuum.

Berwick, R. and Chomsky, N. 2017 Why only us? Language and evolution. Cambridge, MA: MIT Press.

Bourne, J., Kress, G., Street, B.V. and Sealey, A. 1999 National Literacy Strategy: A debate. In O’Brien, T. (ed.), Language and literacies: Selected papers from the Annual Meeting of the British Association for Applied Linguistics, Manchester, September 1998. Clevedon: Multilingual Matters.

Brookes, G., Mullany, L. and Harvey, K. 2018 From corpus to clinic: Health communication, research and the impact agenda. In McIntyre, D. and Price H. (eds), Applying linguistics: Language and the impact agenda. London: Routledge.

Brumfit, C.J. 1995 Teacher professionalism and research. In Cook, G. and Seidlhofer, S. (eds), Principle and practice in applied linguistics. Oxford: Oxford University Press.

Cameron, D. 1996 Performing gender identity: Young men's talk and the construction of heterosexual masculinity. In Johnson, S. and Meinhof, U. (eds), Language and masculinity. Oxford: Blackwell.

Carter, R. 1996 Politics and knowledge about language: The LINC Project. In Hasan, R. and Williams, G. (eds), Literacy and society. London: Longman. pp. 1-21.

Carter, R. (ed.) 1990 Knowledge about language and the curriculum: The LINC reader. London: Hodder.

Chaudron, C. 1988 Second language classrooms: Research on teaching and learning. Cambridge: Cambridge University Press.

CLIE (Committee for Linguistics in Education) 2017 About CLIE. Available at http://clie.org.uk/about-3 [Last accessed 3 January 2019]

Clyne, M. 1968 Zum pidgin deutsch der gastarbeiter. Zeitschrift für Mundartforschung, 35: 130-139.

Cooke, M. and Simpson, J. 2008 ESOL: A critical guide. Oxford: Oxford University Press.

Council of Europe 2001 Common European Framework of Reference for Languages. Cambridge: Cambridge University Press. 
Daborn, E. 2016 Linguistics and knowledge about language in education (LKALE) SIG: Report on the first spring meeting. BAAL Newsletter 109, 29-30.

Davidson, J.M.C. (ed.) 1981 Issues in language education. London: Centre for Information on Language Teaching and Research.

Department of Education and Science (DES). 1988 Report of the committee of inquiry into the teaching of English language under the chairmanship of Sir John Kingman FRS (The Kingman Report). London: HMSO.

Department of Education and Science (DES) 1989 English for ages 5-16 (The Cox Report). London: HMSO.

Donmall, B.G. (ed.) 1985 Language awareness: NCLE papers and reports 6. London: Centre for Information on Language Teaching and Research.

Doughty, P., Pearce, J. and Thornton, G. 1971 Language in use: Schools Council programme in linguistics and English teaching. London: Edward Arnold.

Ellis, S. and Moss, G. 2014 Ethics, education policy and research: The phonics question reconsidered. British Educational Research Journal, 40(2), 241-260.

Giovanelli, M. and Clayton, D. (eds) 2016 Knowing about language: Linguistics and the secondary English classroom. Abingdon/ New York, Routledge.

Goddard, A. 2016 Langauge and linguistics in higher education: Transition and post-16 English. In Giovanelli, M. and Clayton, D. (eds), Knowing about language: Linguistics and the secondary English classroom. Abingdon/New York: Routledge. pp. 210-222.

Hawkins, E. 1984 Awareness of language: An introduction. Cambridge: Cambridge University Press.

Hawkins, E. (ed.) 199730 years of language teaching. London: Centre for Information on Language Teaching and Research.

Heath, S.B. 1983 Ways with words. Cambridge: Cambridge University Press.

Hyland, K. 2012 Disciplinary identities: Individuality and community in academic discourse. Cambridge: Cambridge University Press.

Jones, N. 2007 Assessment and the National Languages Strategy. Cambridge Journal of Education, 37(1): 17-33.

Koester, A. 2011 Workplace discourse. London: Continuum.

Li, W. 2017 Translanguaging as a practical theory of language. Applied Linguistics, 39(1): 9-30.

Lo Bianco, J. 1987 National Policy on Languages. Canberra: Australian Government Publishing Service.

Marsden, E. 2016 Joined up: How do we talk about grammar and texts? Languages Today, 22, 30-32.

Marsden, E. and Kasprowicz, R. 2017 Foreign language educators' exposure to research: reported experiences, exposure via citations, and a proposal for action. Modern Language Journal, Early View. DOI: https://doi.org/10.1111/ modl.12426

Mitchell, R. 1997 Notes on the history of the British Association for Applied Linguistics 1967-1997: British Association for Applied Linguistics. 
Mitchell, R. 2011 Still gardening in a gale: Policy, research and practice in foreign language education in England. Fremdsprachen Lehren und Lernen, 40(1): 49-67.

Mitchell, R. 2013 Making the case for the future of languages. In Driscoll, P., Macaro, E. and Swarbrick, A. (eds), Debates in modern languages education. Abingdon/New York: Routledge.

Mitchell, R. and Myles, F. 2019 Learning French in a UK setting: Policy, classroom engagement and attainable learning outcomes. Apples: Applied Language Studies, 13(1): 69-93.

Moys, A. (ed.) 1984 Foreign language examinations: The 16+ debate 1981-83. NCLE Reports and Papers 5. London: Centre for Information on Language Teaching and Research.

Newsboard 1968 ELT Journal, 22(3): 280-281.

Nicholls, S. and Hoadley Maidment, E. 1993 Current issues in teaching English as a second language to adults - methodology. London: Nelson ELT.

Perdue, C. (ed.) 1993 Adult language acquisition: Cross-linguistic perspectives. Vols 1 \& 2. Cambridge: Cambridge University Press.

Perren, G. (ed.) 1979 The mother tongue and other languages in education. London: Centre for Information on Language Teaching and Research.

Roberts, C. and Baynham, M. (eds) 2006 Where talk is work: The social contexts of adult ESOL teaching. Linguistics and Education, 17(1): 1-106.

Street, B.V. 1984 Literacy in theory and practice. Cambridge: Cambridge University Press.

Teaching Schools Council 2016 Modern foreign languages pedagogy review. Available at https://www.tscouncil.org.uk/wp-content/uploads/2016/12/ MFL-Pedagogy-Review-Report-2.pdf [Last accessed 3 January 2019].

Tinsley, T. and Board, K. 2017 Language trends 2016/17: Language teaching in primary and secondary schools in England. British Council. Available at https:// www.britishcouncil.org/sites/default/files/language_trends_survey_ 2017_0.pdf [Last accessed 3 January 2019].

Trim, J. 1997 A view from the bridge. In Hawkins, E (ed.), 30 years of language teaching. London: Centre for Information on Language Teaching and Research. pp. 321-330.

Widdowson H.G. 1980 Models and fictions. Applied Linguistics, 1/2: 165-170. Reprinted in Widdowson H.G. 1983. Explorations in Applied Linguistics 2. Oxford: Oxford University Press. pp. 21-28.

Wodak, R. 2009 Discourse analysis and courtroom interaction. Discourse Processes, 3(4): 369-380.

Wyse, D. and Torgerson, C. 2017 Experimental trials and 'what works?' in education: The case of grammar for writing. British Educational Research Journal, 43(6): 1019-1048. 